Ignacio Verdugo

\title{
Balada del Camino
}

MANECER fragante a materno cariño;

rumor de alas que ensayan su audacia para el vuelo!...

Yo era un chiquillo ingenuo y en mis ojos de niño aun brillaban las últimas estrellitas del cielo.

Acaso demasiado precoz en la tristeza,

mi corazón sufría de un anhelo impreciso

de amor y sufrimiento, de gloria y de belleza,

vago como un perfume, fuerte como un hechizo.

¡Mañana luminosa de recuerdos de antaño! Atados mis ensueños, igual que un peregrino me los eché a la espalda para no hacerles daño, y ebrio de fe, marchéme a buscar mi camino... ¡El mundo era pequeño para mi loca audacia, para mi sed de gloria, para mi ardor divino!

(Llena eres de gracia, madre, porque me diste esta le en mi Destino).

La ruta era tan amplia, la atmósfera tan clara, que la esperanza estaba en la luz y en las cosas como una cosa viva que de ellas emanara... ¡Y aspiré la mañana como un mazo de rosas! Después, mi alma de niño, con el ansia irrisoria del que quiere asir astros en el agua dormida, partió a buscar la gloria, partió a encontrar la vida. 
Y, lleno de entusiasmo, caminé por la vía como un príncipe joven que, pródigo y glorioso, derrochase su sangre, su oro y su alegría. Mas, al llegar la tarde,-la Hora del Reposo,vi mi error en las zarzas que mi pie enrojecía y el eco atormentado de mi propio sollozo me demostró que aquélla no era la senda mía.

Desde entonces, mi viejo corazón,-ioh idealismo!fué rodando, rodando como una hoja marchita, de pasión en pasión y de abismo en abismo... $\mathrm{Y}$ al fin he comprendido, en la paz infinita de esta hora, aromada de un suave escepticismo, que el camino anhelado, que la senda exquisita iestaba en lo más hondo de mí mismo!

IGNACIO VERDUGO.

Nihuinco, 1922. 